\title{
EATING VEGETABLES BEFORE CARBOHYDRATES DECREASE ENERGY INTAKE OF TYPE-2 DIABETES MELLITUS PATIENTS
}

\author{
Urutan Makan Sayur Sebelum Karbohidrat Menurunkan Asupan Energi pada Pasien Diabetes \\ Melitus Tipe 2
}

\author{
Dian Eka Widyasari ${ }^{1 *}$, Sugiarto ${ }^{2}$, Dono Indarto ${ }^{3}$ \\ ${ }^{1}$ Postgraduate Program of Nutrition Science, Universitas Sebelas Maret, Surakarta, Indonesia \\ ${ }^{2}$ Internal Medicine Major, Faculty of Medicine, Universitas Sebelas Maret Surakarta, Indonesia \\ ${ }^{3}$ Department of Physiology, Faculty of Medicine, Universitas Sebelas Maret, Surakarta, Indonesia \\ *E-mail : diandhanial11@gmail.com
}

\begin{abstract}
Diabetes mellitus is a non-communicable disease that has increased significantly in Indonesia and worldwide. Dietary arrangements through diet therapy are beneficial for improving the performance of the pancreas in producing and stimulating the work of insulin. This study aimed to determine the effect of the order of vegetable and carbohydrate consumptions on the decrease of energy intake. Method used randomized control trial with pre-post design. A total of 24 people with non-complicating type-2 diabetes mellitus aged 18-65 years were assigned into 3 groups; control group (C), vegetable before carbohydrate group (P1), and vegetable with carbohydrate group (P2). Energy intake before and after the intervention was measured using a 24-hours food recall. To compare pre-post intervention, paired T-test were used, meanwhile to compare difference among groups data were analysed using ANOVA. A significant decrease in energy intake was found in P1 where the mean values of C and P1 were $17.75 \pm 12.40 \mathrm{kcal}$ and $155.27 \pm 23.40$ calories $(\mathrm{p}<0.001)$, and mean values of P1 and P2 were $155.27 \pm 23.40 \mathrm{kcal}$ and $4.54 \pm 48.99 \mathrm{kcal}(\mathrm{p}<0.001)$. The order of vegetable before carbohydrate consumption decreases energy intake of type- 2 diabetes mellitus patients.
\end{abstract}

Keywords: diabetes mellitus, energy intake, food order

\section{INTRODUCTION}

Diabetes mellitus (DM) is a noncommunicable disease that is increasing in number in various countries including Indonesia (Perkeni, 2015). The effect of chronic hyperglycemia as one of the typical symptoms of DM is correlated with organ dysfunction and damage, often leading to multiple organ failure. Management of DM aims to control blood glucose levels and prevent further complications that result in organ failure through the implementation of four pillars, namely education, diet therapy, physical activity, and pharmacological therapy (Kemenkes, 2018).

Diet therapy is one pillar that supports the success of controlling blood glucose levels. Energy intake excess spurs insulin resistance through increasing blood glucose levels and the free fatty acids inside blood, apart from that also causes an increase in fat body, causing obesity which is closely related to resistance insulin (Immawati and Wirawanni, 2014). Energy intake for diabetics is $25-30 \mathrm{kcal} / \mathrm{kg}$ ideal body weight depend on nutritional status, age, gender, activity and complications (ADA, 2018).

The order of vegetable and carbohydrate consumptions is one of the nutritional interventions that can be implemented for type-2 diabetes mellitus (DMT2) patients, where eating vegetables before carbohydrates could support the fulfillment of fiber intake as one of the recommended diets for DMT2 patients (Imai et al., 2011). Fiber, especially soluble fiber from vegetables, is useful in controlling blood glucose levels for DMT2 patients. Fiber that enters the digestive tract will slow down the food digestion process in the stomach. Fiber with food will absorb water in the stomach and change food to be more viscous (Wang et al., 2016). This mechanism can prolong satiety and reduce food intake, slowing down the absorption of nutrients including glucose (Tremblay and Bellisle, 2015). This study aims to determine the effect of the order of eating vegetables with carbohydrates on changes in 
energy intake. Previous research related to a decrease in energy intake in diabetics was based on a cross-sectional study, whereas in this study used a different intervention to eat vegetables before and with carbohydrates to analyze the effects of reduced energy intake from both interventions.

\section{METHOD}

In this randomized experimental study with pre-post group design, the subjects willing to participate had been explained about the research procedure and had filled in the informed consent. This study has passed ethical eligibility by the Health Research Ethics Commission of dr. Moewardi General Hospital Surakarta number 136/I/HREC/2020.

This study was conducted in February 2020 with a population of all DMT2 patients. The population of T2DM patients is all outpatients at Manyaran Public Health Center, Semarang City, Central Java in 2019 as many as 1061 people. Determination of research subjects through inclusion criteria and grouping into experimental groups through randomization. The inclusion criteria were DMT2 patients who received oral hypoglycemic drugs, aged 18-65 years, were male or female, like to eat of vegetables, and performed low intensity physical activity. The exclusion criteria were having micro vascular or macro vascular complications (chronic kidney disease, heart disease, and hyperuricemia), having difficulty chewing and swallowing, having gastroenteritis, being pregnant, smoking, taking glucose-lowering supplements/herbal medicines, and getting insulin therapy. The number of research subjects was calculated using the hypothesis testing formula in two populations on average, resulting in 24 subjects including the loss of follow-up with 8 people in each group.

This study was conducted by giving intervention to the subjects in the form of breakfast consisting of rice, animal side dishes, vegetable side dishes, and vegetables. Processing of side dishes and vegetables by sauteing. The caloric value of the intervention menu was obtained from the average nutritional needs of the subjects, and $20 \%$ of its composition was taken as breakfast. The nutritional composition of the average intervention was 387.24 calories of energy, 18.22 grams of protein, 14.60 grams of fat, 53.14 grams of carbohydrates, and 7.07 grams of fiber. The macronutrient composition in the test meal was $14.8 \%$ protein, $20 \%$ fat, and $64.9 \%$ carbohydrates. Subjects were assigned into 3 groups, namely the intervention group eating vegetables before rice/carbohydrates (T1), the intervention group eating vegetables with rice/carbohydrates (T2), and the control group was only given nutrition education in the form of diabetes mellitus diet. The intervention was carried out for 10 days. Before the intervention, the subjects were required to fast for 10 hours; then, in the next morning, the pre-intervention fasting blood glucose levels were measured. After the 10-day intervention, the subjects were also required to fast for 10 hours and their fasting blood glucose levels were measured the next day as post-intervention blood glucose levels. Measurement of fasting blood sugar levels using the hexokinase method, using a spectrophotometer. Venous blood sampling was carried out by analysts from the CITO Laboratory in Semarang. Anthropometric measurements were carried out by researchers.

Bodyweight was measured using a digital weight scale with brand "Digipounds SC-05" a maximum capacity of $180 \mathrm{~kg}$, with an accuracy of $0.1 \mathrm{~kg}$ and height was measured using a wireless body height meter "Gea Medical HT721" with an accuracy of $0.1 \mathrm{~cm}$; both were used to calculate Body Mass Index (BMI) and determine the nutritional needs of each subject.

Data were analyzed using SPSS (Statistical Package for Social Science) version 23.0 For the analysis of the average difference in energy intake, Paired T-Test was used. The data on the effect of the order of vegetable before carbohydrate consumption on the decrease in energy intake using ANOVA test are presented in mean $\pm \mathrm{SD}$.

Table 1. Components of Breakfast Meal Test in Research Subjects

\begin{tabular}{lc}
\hline \multicolumn{1}{c}{ Menu Order } & Amount (gram) \\
\hline Rice & 100 \\
Animal based protein & 50 \\
plant-based protein & 50 \\
Vegetable & 100 \\
Oil & 5
\end{tabular}


The $\mathrm{p}$-value was determined with a significance level of $<0.05$. The composition and type of food in the vegetable eating order treatment group can be seen in Table 1.

\section{RESULT AND DISCUSSION}

A total of 9 women and 15 men with DMT2 who received oral blood-glucose-lowering drug therapy participated in this study. Most of the research subjects were male and the ages between groups were not significantly different. More than $50 \%$ of the subjects were overweight. There were differences in food intake before the intervention in the three groups; intake of protein, fat, carbohydrates and fiber. Confounding variables were controlled by means of strict randomized subject selection and based on inclusion and exclusion criteria.

Energy intake data before and after the study were obtained based on the average energy intake using the 24-hours food recall method. Changes in average energy intakes before and after the study can be seen in Table 3 .

Based on the results of the study, the group eating order of vegetables before carbohydrates significantly decreased energy intake during the 10 days of intervention $(p=0.000)$. In line with research (Imai et al., 2014) that vegetables eaten before protein and carbohydrates can reduce energy intake and increase fiber intake from vegetables.

The decrease in energy intake is a goal of dietary therapy management in patients who want to consume large portions of food (Raynor, 2014), such as DMT2 patients. The results of this study indicated that the patient's energy intake was within the normal basal metabolic limit (25$30 \mathrm{kcal} / \mathrm{kg}$ IBW). Furthermore, at the level of fasting blood sugar levels, it can also be seen that a decrease in energy intake was significant ( $p<$ 0,001 ) in the T1 group (Table 4). A calorie deficit can have an impact on weight loss and repair of pancreatic beta cells and insulin sensitivity, so that blood sugar levels are controlled (Zubrzycki et al., 2018).

In this study, the strategy of reducing energy intake through the meal order method, namely prioritizing vegetable consumption before carbohydrates and protein, means reducing energy intake and controlling blood sugar. Control of food consumption can be promoted through dietary arrangements that can reduce food intake. One approach that can help prevent excess food intake is achieving an optimal satiety response (Gibbons et al., 2019).

In this study, the level of satiety was determined by the order of food consumption method, namely sorting the type of food to consume. Prioritizing vegetable consumption

Table 2. Characteristic of Respondence

\begin{tabular}{|c|c|c|c|c|}
\hline \multirow{2}{*}{ Characteristic } & \multicolumn{3}{|c|}{ Research Group } & \multirow{2}{*}{$\mathbf{p}$} \\
\hline & $C(n=8)$ & $T 1(n=8)$ & $T 2(n=8)$ & \\
\hline Age (year) & $55.63 \pm 3.66$ & $57.00 \pm 4.47$ & $55.50 \pm 5.45$ & $0 . .771$ \\
\hline Weight (kg) & $66.31 \pm 7.31$ & $62.91 \pm 10.63$ & $64.60 \pm 14.24$ & 0.833 \\
\hline Height (m) & $1.54 \pm 7.63$ & $1.53 \pm 4.66$ & $1.56 \pm 10.25$ & 0.722 \\
\hline BMI $\left(\mathrm{kg} / \mathrm{m}^{2}\right)$ & $27.68 \pm 3.15$ & $27.34 \pm 4.94$ & $2.68 \pm 4.35$ & 0.962 \\
\hline \multicolumn{5}{|l|}{ Nutritional Status } \\
\hline Normal & $1(12.5 \%)$ & $2(25 \%)$ & $2(25 \%)$ & \multirow{2}{*}{0.777} \\
\hline Overweight & $7(87.5 \%)$ & $6(75 \%)$ & $6(75 \%)$ & \\
\hline Duration of DM (year) & $3.63 \pm 1.84$ & $6.25 \pm 4.95$ & $3.25 \pm 0.70$ & 0.129 \\
\hline \multicolumn{5}{|l|}{ Sex } \\
\hline Male & $2(25 \%)$ & $6(75 \%)$ & $7(87.5 \%)$ & \multirow{2}{*}{0.741} \\
\hline Female & $6(75 \%)$ & $2(25 \%)$ & $1(12.5 \%)$ & \\
\hline \multicolumn{5}{|l|}{ Drug Therapy } \\
\hline Biguanid & $4(50 \%)$ & $1(12.5 \%)$ & $0(0 \%)$ & \multirow{3}{*}{0.085} \\
\hline Sulfonylurea & $0(0 \%)$ & $0(0 \%)$ & $1(12.5 \%)$ & \\
\hline Combination & $4(50 \%)$ & $7(87.5 \%)$ & $7(87.5 \%)$ & \\
\hline
\end{tabular}


Table 3. Average of Energy Intake Before and After Dietary Intervention

\begin{tabular}{lcccc}
\hline \multirow{2}{*}{ Group } & \multicolumn{3}{c}{ Energy Intake (kcal) } & \multirow{2}{*}{$\mathbf{p}$} \\
\cline { 2 - 4 } & Before & After & $\Delta($ Mean \pm SD) & 0.004 \\
C & $1100.70 \pm 265.59$ & $1084.70 \pm 265.45$ & $17.75 \pm 12.40$ & $<0.001$ \\
T1 & $1149.31 \pm 121.45$ & $994.03 \pm 135.23$ & $155.27 \pm 23.40$ & 0.801 \\
T2 & $1207.10 \pm 154.49$ & $1202.56 \pm 175.16$ & $4.54 \pm 48.99$ & 0 \\
\hline
\end{tabular}

Data in the form of mean $\pm \mathrm{SD}$, Paired T-Test. Significance level $\mathrm{p}<0.05$.

Table 4. Average of Blood Fasting Glucose Before and After Dietary Intervention

\begin{tabular}{lcccc}
\hline \multirow{2}{*}{ Group } & \multicolumn{3}{c}{ Blood Fasting Glucose (mg/dL) } & \multirow{2}{*}{$\mathbf{p}$} \\
\cline { 2 - 4 } & Before & After & $\Delta$ (Mean \pm SD) & 0.396 \\
C & $104.50 \pm 36.84$ & $94.0 \pm 10.90$ & $-10.50 \pm 32.81$ & $0.001^{*}$ \\
T1 & $148.88 \pm 100.88$ & $100.88 \pm 14.59$ & $-48.00 \pm 23.19$ & 0.145 \\
T2 & $167.00 \pm 98.70$ & $137.38 \pm 98.70$ & $-29.62 \pm 51.16$ & 0.16 \\
\hline
\end{tabular}

Data in the form of mean \pm SD, Paired T-Test. Significance level $\mathrm{p}<0.05$.

Table 5. Average Difference in Energy Intake After Intervention

\begin{tabular}{lcc}
\hline Group (n=8) & $\begin{array}{c}\text { Difference in energy } \\
\text { intake (kcal) }\end{array}$ & p \\
\hline $\mathrm{C}$ & $17.75 \pm 12.40$ & $<0.001$ \\
$\mathrm{~T} 1$ & $155.27 \pm 23.40$ & \\
$\mathrm{C}$ & $17.75 \pm 12.40$ & 0.694 \\
$\mathrm{~T} 2$ & $4.54 \pm 48.99$ & \\
$\mathrm{~T} 1$ & $155.27 \pm 23.40$ & $<0.001$ \\
$\mathrm{~T} 2$ & $4.54 \pm 48.99$ & \\
\hline
\end{tabular}

Data in the form of mean $\pm \mathrm{SD}$, Anova. Significance level $\mathrm{p}<0.05$.

before carbohydrates can significantly improve the satiety response of DMT2 patients (Kimiko et al., 2018). Vegetables are a highly-recommended food component for consumption by DMT2 patients (Toumpanakis, Turnbull and Alba-barba, 2018). Vegetables as one type of soluble fiber play a role in optimizing the satiety response. The fiber that first enters the digestive tract with water will be more viscous so that the digestive process runs slower and has gastric retention to the small intestine, resulting in long-lasting satiety (Mahan and Raymond, 2016).

Furthermore, undigested fiber is fermented by bacteria in the colon and produces SCFA (Short Chain Fatty Acids) which has the potential to improve insulin sensitivity and blood glucose levels (Hervik, 2019). SCFA regulates satiety response with its important role in regulating appetite. It can bind to FFA (Free Fatty Acid 2 and 3) receptors in L cells of the small intestine. These cells are endocrine cells that produce hormone peptide YY (PYY) and Glucagon Like Peptide (GLP-1) which play a role in decreasing appetite and the amount of food intake (Wanders et al., 2011).

The presence of fat and protein will result in the release of cholecystokinin (CCK), whereas glucagon-like peptide 1 and peptide YY (PYY) result from more distal responses (Chaudhri, Small and Bloom, 2006). Also, the viscous nature of fiber causes distension in the stomach, which triggers a signal of satiety and has an effect on reducing food intake (Kristensen and Jensen, 2011).

Other nutrients that must be controlled in controlling blood sugar are carbohydrates. Carbohydrates will be metabolized into glucose in the presence of the hormone insulin. Glucose requires the insulin hormone to stimulate the entry of glucose into in cells to be used as a source of energy and helps store glycogen in cells muscles and heart (Mahan and Raymond, 2016). Data on the amount of intake and types of carbohydrates were not obtained in this study. This is one of the weaknesses in this study.

\section{CONCLUSION}

The order of vegetable before carbohydrate consumption decreases energy intake of type-2 diabetes mellitus patients. This method can be used as an alternative for nutrition education in the management of nutritional therapy for type- 2 diabetes mellitus patients. In further research, it is 
necessary to investigate the effect of the order of eating vegetables on changes in blood sugar levels, as the main indicator of the success of diet therapy and the effect on weight loss, because the most of subject in this study were overweight.

\section{ACKNOWLEDGMENT}

The researchers would like to thank the Head of Manyaran Public Health Center Semarang City and the medical team, as well as the respondents who have been willing to participate in this study.

\section{CONFLICT OF INTEREST}

No potential conflicts of interest were disclosed.

\section{REFERENCES}

American Diabetes Association. (2018). 4. Lifestyle management: standards of medical care in diabetes-2018. Diabetes care, 41(Supplement 1), S38-S50.

Chaudhri, O., Small, C. and Bloom, S. (2006) 'Gastrointestinal hormones regulating appetite', Philosophical Transactions of the Royal Society B: Biological Sciences, 361(1471), 1187-1209.

Gibbons, C., Hopkins, M., Beaulieu, K., Oustric, P., \& Blundell, J. E. (2019). Issues in measuring and interpreting human appetite (satiety/ satiation) and its contribution to obesity. Current obesity reports, $8(2), 77-87$.

Hervik, A. K., \& Svihus, B. (2019). The role of fiber in energy balance. Journal of nutrition and metabolism, 2019.

Imai, S., Matsuda, M., Hasegawa, G., Fukui, M., Obayashi, H., Ozasa, N., \& Kajiyama, S. (2011). A simple meal plan of'eating vegetables before carbohydrate'was more effective for achieving glycemic control than an exchangebased meal plan in Japanese patients with type 2 diabetes. Asia Pacific journal of clinical nutrition, 20(2), 161-168.

Immawati, F.R. \& Wirawanni, Y. (2014). Hubungan konsumsi karbohidrat, konsumsi total energi, konsumsi serat, beban glikemik dan latihan jasmani dengan kadar glukosa darah pada pasien diabetes mellitus tipe 2. Diponegoro Journal of Nutrition and Health, 2(3), 89842.
Kementrian Kesehatan RI. 2018. Riset Kesehatan Dasar. Jakarta: Kemenkes RI. Retrived from http://www.depkes.go.id/resources/download/ infoterkini/materi_rakorpop_2018/Hasi1\%20 Riskesdas\%202018.pdf

Kristensen, M., \& Jensen, M. G. (2011). Dietary fibres in the regulation of appetite and food intake. Importance of viscosity. Appetite, 56(1), 65-70

Mahan, L. K., Raymond, J. L., Escott-stump, S., \& Krause's Food, N. (2016). Diet therapy. Copyright Elsevier (USA). All rights reserved, 2, 135-143.

Nishino, K., Sakurai, M., Takeshita, Y., \& Takamura, T. (2018). Consuming carbohydrates after meat or vegetables lowers postprandial excursions of glucose and insulin in nondiabetic subjects. Journal of nutritional science and vitaminology, 64(5), 316-320.

Perkeni, P. (2019). Pedoman pengelolaan dan pencegahan diabetes melitus tipe 2 dewasa di Indonesia. Edisi Pertama. Jakarta: PB Perkeni.

Raynor, H. A. (2014). What to do about portion sizes? Roundtable discussion at the Forefronts in Portion Size Conference. International Journal of Obesity, 38(1), S34-S36.

Toumpanakis, A., Turnbull, T., \& Alba-Barba, I. (2018). Effectiveness of plant-based diets in promoting well-being in the management of type 2 diabetes: a systematic review. BMJ Open Diabetes Research and Care, 6(1).

Tremblay, A., \& Bellisle, F. (2015). Nutrients, satiety, and control of energy intake. Applied Physiology, Nutrition, and Metabolism, 40(10), 971-979.

Wanders, A. J., van den Borne, J. J., de Graaf, C., Hulshof, T., Jonathan, M. C., Kristensen, M., ... \& Feskens, E. J. (2011). Effects of dietary fibre on subjective appetite, energy intake and body weight: a systematic review of randomized controlled trials. Obesity reviews, 12(9), 724739.

Wang, P. Y., Fang, J. C., Gao, Z. H., Zhang, C., $\&$ Xie, S. Y. (2016). Higher intake of fruits, vegetables or their fiber reduces the risk of type 2 diabetes: A meta-analysis. Journal of diabetes investigation, 7(1), 56-69.

Zubrzycki, A., Cierpka-Kmiec, K., Kmiec, Z., \& Wronska, A. (2018). The role of low-calorie diets and intermittent fasting in the treatment of obesity and type-2 diabetes. $J$ Physiol Pharmacol, 69(5), 663-83. 